\title{
Social Workers as Civic-Minded Professionals
}

\author{
Sarah E. Twill \\ Laura A. Lowe
}

\begin{abstract}
This study examined civic-mindedness among a sample of social work educators, community practitioners and new graduates. Using a web-based survey, researchers administered Hatcher's (2008) Civic-Minded Professional scale. Results indicated that traditional and field faculty were more civic-minded than new graduates and other practitioners. Social work educators who focused on raising civic awareness in courses were more civic-minded than colleagues. New graduates who had participated in club service events were more civic-minded; however, there was no significant differences between groups based on number of community service courses completed. Social workers, whether faculty or not, who had participated in collaborative research were more civicminded. The authors conclude that how social workers view their commitment to civic engagement has implications. Social workers need to be vigilant in our commitment to well-being in society. Intentional practices could be implemented to strengthen the partnership among groups.
\end{abstract}

Keywords: Civic-mindedness, community service, social work profession, social work education

Most famously documented in Putnam's Bowling Alone (2000), civic life and investment in social capital has deteriorated in the United States. Membership in civic organizations (Putnam, 2000), attendance at religious services (Pond, Smith, \& Clement, 2010), voter turnout (Bipartisan Policy Center, 2012), and marriage rates (Cohn, Passel, Wang, \& Livingston, 2011) have all waned. Others suggest that reliance on individual rather than public transportation (Gillham, 2002), the proliferation of consumption of media entertainment at home rather than in public (Taylor, Funk, \& Craighill, 2006), and working long hours (Organization for Economic Cooperation and Development [OECD], 2011) have weakened individuals' connections to others. In a time when individuals are more likely to be electronically connected to each other via the internet, smart phones, Facebook, Twitter, Instagram, and other social media, how we view connectedness to others is increasingly complicated (Gil de Zuniga \& Valenzuela, 2011; Hampton, Goulet, Marlow, \& Rainie, 2011, 2012; Zhang \& Chia, 2006). Perhaps related, Putnam (2000) even suggests that Americans are a people who over-estimate the value of individual contributions rather than collective influences.

The OECD's Better Life Index (2011) may help explain Americans' focus on the individual. This index goes beyond the gross domestic product (GDP) to examine 11 topics (e.g., education, housing, life satisfaction) that are related to material earnings and contribute to quality of life. In looking at the index on work-life balance, $11 \%$ of employees in United States work "very long hours", defined as over 50 hours a week. In some countries (e.g., Netherlands, Sweden), only 1-2\% of employees work over 50 hours a week.

\footnotetext{
Sarah E. Twill, Ph.D., MSW, is an Associate Professor of Social Work at Wright State University in Dayton, OH. Laura A. Lowe, Ph.D., MSW, is an Associate Professor and Social Work Program Director in the Department of Sociology, Anthropology, and Social Work at Texas Tech University in Lubbock, TX.

Copyright (C) 2014 Advances in Social Work Vol. 15 No. 2 (Fall 2014), 278-293
} 
Hours spent working directly impacts time available for leisure activities. According to the OECD data, Americans have an average of 14.3 hours per day to use for personal care (e.g., eating, sleeping) and leisure (e.g., socializing with friends and family, watching TV). The U.S. ranks $30^{\text {th }}$ out of 36 countries in availability of free time. Individuals in countries such as Estonia, Poland, Japan, and Mexico have less leisure time, while citizens of Norway and Denmark enjoy an average of 16 hours of leisure time per day.

In spite of more employees working long hours, and identifying little free time, Americans still use part of their leisure time to volunteer (OCED, 2011). They volunteer about one hour per week, double the OCED average. The OCED Index also examines civic engagement; however, only rates of voter turnout, participation in political activities, confidence in macro systems (i.e., judicial system, government, the media), and consultation in rule-making are considered in the index. However, the authors still draw the conclusion that there are differences in how the citizenry practice civic engagement. Older individuals with more education and higher incomes participate in political activities, including turning out to vote, more than those with fewer of these assets.

\section{The Civic-Minded Professional and Social Work}

Hatcher (2008) defined the civic-minded professional as one who, "a) is skillfully trained through formal education $b$ ) with the ethical disposition as a social trustee, and c) the capacity to work with others in a democratic way, d) to achieve public good" (p. 21). So, measuring this concept involves determining to what extent a person knows about issues impacting his or her community, and how he or she acts on that knowledge for the betterment of the community.

A civic-minded professional sees him or herself as a trustee of knowledge (Colby \& Sullivan, 2009; Sullivan \& Rosin, 2008). Building on that work, Hatcher (2008) demands that civic-minded professionals act on that knowledge in order to promote the public good. As such, the concept of the civic-minded professional consists of the intersection of three domains: self-identity, one's work-career-profession, and civic attitudes and actions (Hatcher, 2008). Based on this assumption, Hatcher developed the Civic-Minded Professional Scale; five factors are included in the scale (voluntary action; identity and calling; citizenship; social trustee; and consensus building).

The definition of a civic-minded professional parallels many of the values of the social work profession. Therefore, the question of civic-mindedness and engagement has unique ramifications for social workers because the values of the profession imply that such commitment and action is a requirement, not an optional skill to be developed. Most specifically, the social work values of social justice and service (National Association of Social Workers [NASW], 2008) are embedded in Hatcher's (2008) definition of a civicminded professional. The call of ethical engagement for the public good overlaps with social work's commitment to creating a just world where all individuals are allowed to thrive and achieve their full potential.

However, not all social workers embrace the values of the profession in the same way. The profession's move away from groupwork, affiliated with the settlement houses and a focus on social change, towards a model centering on individual cases, permitted social 
work (and those educating future social work professionals) to concentrate resources towards micro issues (Morris, 2000; Specht \& Courtney, 1994). Morris (2000) wrote, "By 1990 the field was primarily involved in interpersonal and mental health kinds of careers, while work to change conditions remained at the rhetorical level rather than providing jobs and institutional opportunities to work for change" (p. 45). Similarly, Specht and Courtney (1994) argued that social workers became "unfaithful angels" as they attended to the psychotherapeutic needs of the individual, rather than addressing the original purpose of the social work profession as change agents. They state:

Social workers should not be secular priests in the church of individual repair; they should be the caretakers of the conscience of the community. They should not ask, "Does it feel good to you?" They should help communities create good. There must be a profession that provides a vision that enables us to direct our energies to the creation of healthy communities. (pp. 28-29)

How social workers, who have the ability to influence social work practice, see their roles not just as social workers, but as citizens, is important.

Social workers have a long history of commitment to the community beginning with the work of Jane Addams and Ellen Starr (Kenny \& Gallagher, 2002). The philosophy of the settlement house movement called for a commitment to community outreach. Today, that same commitment to community can be seen in higher education's commitment to service-learning pedagogies. King (2003) wrote about social work's history with the pedagogy and the positive outcomes it creates for students, faculty, and the community groups with whom they partner. "Experiential learning, civic responsibility, and evidenced-based practice is the very foundation of social work practice and education" (p. 376) postulated Norris and Schwartz (2009). Further, the use of service-learning as a pedagogy may influence social work practice outcomes (Bransford \& Choi, 2012; Lowe \& Medina, 2010; Mink \& Twill, 2012; Rocha, 2000; Williams, King, \& Kobb, 2002).

Likewise, as field experience is the signature pedagogy of the profession (Council on Social Work Education [CSWE], 2008), field supervisors also have educator roles in shaping the next generation of social workers. Mary (2001) surveyed MSW field educators about their political involvement. She found that social workers in public agencies were more active than those in private agencies. The values and behaviors exhibited by field instructors may be transmitted and modeled to students whom they supervise. Related, Ritter (2008) surveyed licensed social workers about their political participation. Using Verba, Schlozman, and Brady's (2000) citizen participation model to explain why individuals engage in the political process, she found that National Association of Social Workers (NASW) membership (classified as a recruitment network under the Verba et al. model) was a significant predictor of political participation.

Gibelman and Sweifach (2008) studied nearly 1,550 licensed social workers' volunteer behaviors and charitable giving. They found that nearly $90 \%$ had volunteered during their lifetimes; however, only about $50 \%$ had volunteered in the past two years. Those who had never volunteered indicated that their professional obligations as a social worker was a kind of volunteering. Financially, social workers gave under $\$ 1,000$ per year to charitable causes. The primary motivation for both volunteering and giving was to "help others." 
Finally, the attitudes of graduating social work students may set the tone for the future of the profession. While not focused solely on social work students, Fenzel and Payrot (2005) found that being civically engaged during college increased post college attitudes about social responsibility, political participation, and volunteerism. Participants who engaged in service-learning courses had higher engagement scores that those who participated in general community service experiences. Similarly, Astin, Sax, and Avalos (1999) examined behavioral indicators and found that those who had volunteered in college were more likely to donate money to their undergraduate institutions, continue to volunteer after college, and socialize with more diverse people than those who were not civically engaged.

\section{Methods}

This study sought to explore civic-mindedness among social workers. Particularly, the researchers were interested in whether social work educators who used pedagogies that emphasized civic responsibility were different from faculty members who did not, in terms of civic-mindedness. Additionally, the researchers were interested in how civicmindedness might differ between different groups of social workers, such as educators, community practitioners and newly practicing social workers.

Permission to conduct the research was granted by the Institutional Review Boards (IRB) of each author's university. Between June and December of 2012 information was collected from social work educators, community social workers, and graduating social work seniors. Because the research presented no more than minimal risk of harm to subjects and involved no procedures for which consent was normally required outside the research context, participants gave implied consent when they completed the online survey. Some students filled out paper surveys; these participants gave written consent. All respondents were informed that their participation was not required and would have no impact on their relationship with the researchers or their universities. Participants were provided with IRB contact information.

\section{Survey}

The researchers administered the survey using Qualtrics, a web-based survey service. Respondents answered up to 84 questions. The majority of survey items were closed-ended with forced choice response options. Attitudinal items were primarily Likert-type items with response options from strongly agree to strongly disagree. The survey used a skip pattern based on a qualifying question that inquired about respondents' status as a university-based faculty member, a community practitioner with significant field faculty experience, a community practitioner without that status, and students finishing a bachelor's degree in social work. Some survey items were unique for each of these groups. It was estimated that the survey took about 15 minutes for most respondents to complete.

Topics of the survey included demographic items, such as gender and ethnic belonging, questions asked about respondents' participation in a variety of activities, such as volunteering or supervising a social work student in field placement, and other questions that asked about the frequency of certain behaviors, such as donating money to charity or 
going to religious services. Forty-four of the survey items made up the dependent variable, civic-mindedness. Missing responses making up the CMP scale were replaced with a series mean if individuals skipped $1(n=7)$, or $2(n=42)$ items; seven surveys were dropped because they skipped more than two questions on the CMP scale.

\section{Civic-Minded Professional Scale.}

The Civic-Minded Professional (CMP) scale was developed by Hatcher (2008). Her initial scale was made up of 32 items and had an alpha reliability coefficient of .95 . Since that time, the scale has been revised to include 45 questions with three constructs. For this study, the researchers used a modified version of Hatcher's scale, which included 44 items and demonstrated good reliability (Chronbach's alpha $=.93$ ) in the sample. Therefore, the dependent variable, CMP scores, had possible values from 44 to 308, with lower scores on the scale indicating higher levels of civic-mindedness.

\section{Participant Recruitment}

The researchers sought the participation of three main groups of social workers. Social work educators were primarily recruited through the Association of Baccalaureate Social Work Program Directors (BPD) listserv; approximately 1,000 people are registered for this listserv. An invitation was posted in September 2012, with a follow-up posting a few weeks later.

Community social workers were recruited through two lists in September of 2012 with a follow-up contact a few weeks later. At the first author's institution, an email distribution list maintained by the department of "Friends of the Department" (e.g., alumni, donors, adjuncts) was used, and in the second author's community, an invitation was posted on the listserv for the local chapter of NASW. In order to increase participation, invitations requested that readers forward the information to colleagues who might be interested in participating in the study.

Graduating social work students were recruited in spring of 2012 but differently by institution. Graduating seniors from the first author's institution were asked to participate in the survey approximately two weeks before graduation. The students signed an informed

consent in order to participate. The students were asked to participate during the last 15 minutes of a session in a course that enrolled only graduating seniors. Those who did not wish to participate engaged in study activities. At the second author's institution, an announcement was made in senior seminar, which was followed by an e-mail, with a link to the online survey.

\section{Participant Description}

Demographic data on respondents is presented in Table 1. Most of the respondents were from either Ohio (27.4\%) or Texas (29.2\%), the researchers' states; however, 34 other states were also identified and one respondent did not live in the continental U.S. In the sample, the minimum CMP score was 49 and the maximum was $170(\mathrm{M}=91.1, \mathrm{SD}=$ 24.3). 
Table 1. Demographic Characteristics of Respondents

\begin{tabular}{|c|c|c|c|c|}
\hline & $\begin{array}{r}\text { Full Sample } \\
(\mathrm{N}=269)\end{array}$ & $\begin{array}{r}\text { Educators } \\
(\mathrm{n}=111)\end{array}$ & $\begin{array}{r}\text { Community } \\
(\mathrm{n}=103)\end{array}$ & $\begin{array}{r}\text { New Grads } \\
(\mathrm{n}=41)\end{array}$ \\
\hline \multicolumn{5}{|l|}{ Gender } \\
\hline$\%$ Male & 13.7 & 20.2 & 10.5 & 4.9 \\
\hline$\%$ Female & 86.3 & 79.8 & 89.5 & 95.1 \\
\hline \multicolumn{5}{|l|}{ Marital Status } \\
\hline$\%$ Married & 58.3 & 67.3 & 61.7 & 22.0 \\
\hline$\%$ Long partner & 9.4 & 9.7 & 10.6 & 7.3 \\
\hline$\%$ Divorced & 10.2 & 9.7 & 9.6 & 12.2 \\
\hline$\%$ Widowed & 3.1 & 4.4 & 3.2 & 0.0 \\
\hline$\%$ Never married & 18.9 & 8.8 & 14.9 & 58.5 \\
\hline \multicolumn{5}{|c|}{ Children under 18 years residing with respondent } \\
\hline$\%$ Yes & 28.2 & 28.3 & 31.6 & 24.4 \\
\hline \multicolumn{5}{|l|}{ Ethnicity } \\
\hline$\%$ Black & 7.1 & 2.7 & 7.4 & 17.1 \\
\hline$\%$ White & 83.1 & 88.5 & 80.0 & 78.0 \\
\hline$\%$ Latino/a & 3.5 & 2.5 & 3.9 & 4.8 \\
\hline$\%$ Other & 5.9 & 5.3 & 7.4 & 4.9 \\
\hline$\%$ Bi-Multi & 3.9 & 3.5 & 5.3 & 0.0 \\
\hline \multicolumn{5}{|c|}{ Membership in professional organization } \\
\hline$\% \mathrm{CSWE}$ & 34.0 & 72.6 & 1.1 & 0.0 \\
\hline$\% \mathrm{BPD}$ & 26.4 & 58.4 & 0.0 & 0.0 \\
\hline$\%$ NASW & 52.4 & 75.2 & 32.3 & 31.6 \\
\hline$\%$ Other & 33.6 & 49.6 & 25.8 & 5.3 \\
\hline \multicolumn{5}{|l|}{ Age } \\
\hline$\% 21-30$ & 14.5 & 1.8 & 14.7 & 51.2 \\
\hline$\% 31-40$ & 16.9 & 18.6 & 11.6 & 26.8 \\
\hline$\% 41-50$ & 26.3 & 25.7 & 32.6 & 12.2 \\
\hline$\% 51-60$ & 26.3 & 34.5 & 24.2 & 9.8 \\
\hline$\% 61+$ & 16.1 & 19.5 & 16.8 & 0.0 \\
\hline
\end{tabular}

Of the 114 social work educators ( $45 \%$ of the sample), $17.5 \%$ reported their rank as professor, $28.9 \%$ associate, $21.1 \%$ assistant, and $33 \%$ reported a different educator rank. The largest proportion reported having a doctorate in social work $(41.2 \%)$, while $36 \%$ had an MSW and others reported degrees in related fields. While $97 \%$ of the educator sample believed that preparing students for responsible citizenship was integral during 
undergraduate education, only $65 \%$ said there was a high level of commitment at their campus towards this effort.

Among the community social workers (39.3\% of the sample), 42 respondents reported that they regularly supervised field students, while 61 respondents said they did not regularly serve in this function. Community practitioners had a spread of years of social work experience with $29.5 \%$ having less than 10 years, $33.6 \%$ with $11-20$ years, and $36.9 \%$ with $21+$ years. About $34 \%$ had a BSW only, while $48 \%$ had an MSW, 3.2\% a doctorate in social work, and $14.8 \%$ reported that their highest degree was in a related field.

Graduating students $(n=41)$ made up $15.2 \%$ of the overall sample. Only about $5 \%$ had taken and passed the Association of Social Work Board's national BSW licensing exam; most had not yet scheduled an appointment to take it. About $31 \%$ were currently seeking social work employment, $26 \%$ had already secured such employment, $21 \%$ were starting a graduate program in social work and $23 \%$ were engaged in some other employment or personal pursuit. Students had completed their field placements in a variety of different settings including child welfare, family services, mental health, corrections, health, school social work, aging, veterans, cash assistance program and other non-profit settings.

\section{Results}

To begin the examination of civic-mindedness, the researchers conducted some preliminary analysis for the full sample. Standard multiple regression was conducted to determine the contribution of gender, non-dominant status, age, education, and attendance at religious services in predicting CMP scores. The resulting model was significant $\left[R^{2}=\right.$ $\left..069, R^{2 a d j}=.050, F(4,199)=3.67, \mathrm{p}=.007\right]$. However, only age and education made contributions to the model and little variance was explained. Nevertheless, these variables were inversely related to CMP scores.

CMP scores were also lower (more civic-minded) among respondents who reported more political activity. These differences were found to be statistically significant $[\mathrm{F}(3$, $246)=4.0, \mathrm{p}=.008]$; those who reported they had not participated in the past 3 years had significantly higher CMP scores than those who had done so frequently. This influence had a small to moderate effect size (Eta-squared $=.05$ ).

A significant relationship was also indicated between CMP scores and membership in NASW $[\mathrm{t}=3.08, \mathrm{p}=.002]$. NASW members $(\mathrm{M}=86.3, \mathrm{SD}=20.8)$ scored significantly lower (more civic-minded) than non-members $(\mathrm{M}=95.8, \mathrm{SD}=27.3)$. The effect size for this result was small to moderate (Cohen's $d=.39$ ).

Not surprisingly, volunteering appeared to have a stronger impact on CMP scores; this effect size was large (Eta-squared $=.13$ ). Post-hoc comparisons for this significant ANOVA analysis $[\mathrm{F}(3,246)=11.9, \mathrm{p}<.001]$ indicated that those respondents who said they volunteered frequently scored statistically lower (more civic-minded) than those who did so less than occasionally. Further, those who volunteered occasionally scored lower than those who never volunteered.

Next, the researchers addressed the central questions of whether different groups of social workers (educators, field supervisors, community workers, new graduates) were 
different in their attitudes. First, the researchers compared the groups on their attitudes towards volunteering and financial donation. Overall, more than half of the sample indicated that their jobs fulfilled their obligation to volunteer. An ANOVA analysis indicated that there was no significant difference $(p=.07)$ between groups on this issue. Fewer social workers thought that their jobs fulfilled their obligation to donate money ( $31 \%$ of sample). The ANOVA analysis for differences between groups on this issue did reach significance $[\mathrm{F}(3,258)=2.91, \mathrm{p}=.04]$, though post-hoc comparisons indicated no significant contrasts. In this case, social work educators indicated the least agreement with the idea that their jobs fulfilled their obligation of financial donation while new graduates indicated the most agreement.

The researchers also addressed the central question of whether different groups of social workers scored differently on CMP (see Figure 1). Results of an ANOVA analysis indicated that there were significant differences between groups $[F(3,258)=9.7, p<.001]$; this effect size was large (Eta-squared $=.10)$. Post-hoc comparisons suggested that both university-based and field faculty had significantly lower scores (more civic-minded) than either new graduates or "other" community social workers (those without significant field supervision); however no significant difference was found between faculty (whether university or field) or between new graduates and community social workers without regular field students.

Figure 1. Mean Plot of Civic-Mindedness by Type of Social Worker

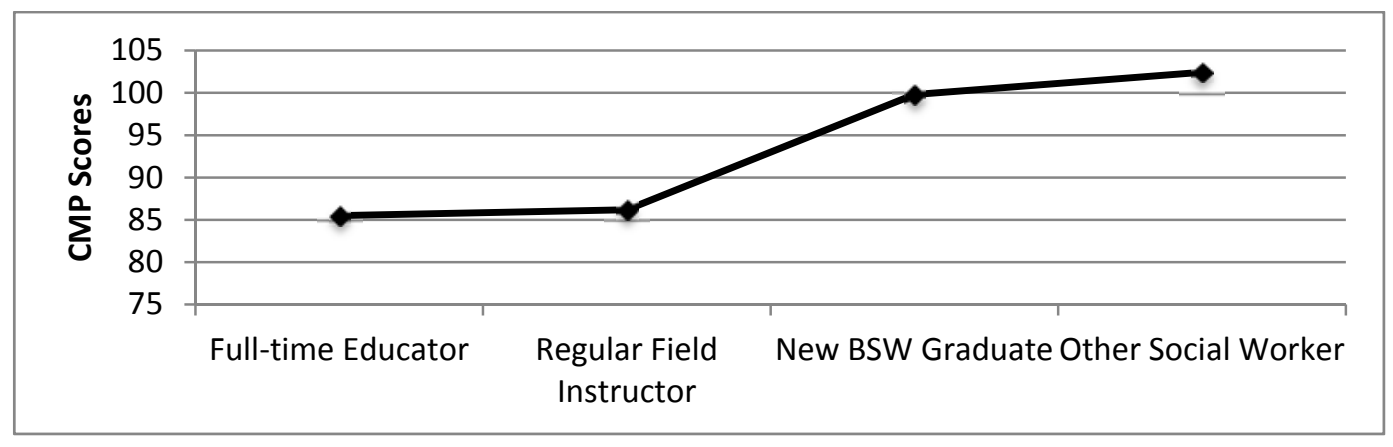

\section{Faculty Participants}

Research participants who indicated that they were faculty members at educational institutions were asked some unique questions. An ANOVA analysis comparing CMP scores by different types of faculty positions (instructors, assistant professors, associate professors, etc.) was not statistically significant $(\mathrm{p}>.05)$. Additionally, no difference in CMP scores were found when comparing faculty members who had memberships with CSWE or Baccalaureate Program Directors (BPD) (related professional organizations) to those that did not.

Faculty respondents were asked how often they had participated in particular activities during the past three years. Faculty who used community service in their pedagogy scored lower (more civic-minded) on the CMP scale (see Figure 2). However, because $61 \%$ of the 
sample indicated that they frequently used this method in their teaching, the researchers combined the less than frequent users into one group for statistical comparison. An independent sample t-test indicated that the difference between the two resulting groups was significant $[\mathrm{t}(112)=2.72, \mathrm{p}=.008]$; this effect size was moderate $($ Eta-squared $=.076)$. Further, social work educators who indicated more frequent use of materials or activities intended to promote student civic engagement also had lower CMP scores (more civicminded). However, because $61 \%$ of faculty reported that they frequently did so, other groups were again collapsed. An independent sample t-test indicated that there was a significant difference $(t=5.72, p<.001)$ between the mean score of the frequent group (M $=77.1, \mathrm{SD}=18.0)$ and the less than frequent group $(\mathrm{M}=98.0, \mathrm{SD}=20.4)$. This effect size was large $($ Eta-squared $=.23)$.

Figure 2. Mean Plot of Civic-Mindedness of Faculty by Use of Community Service Pedagogies

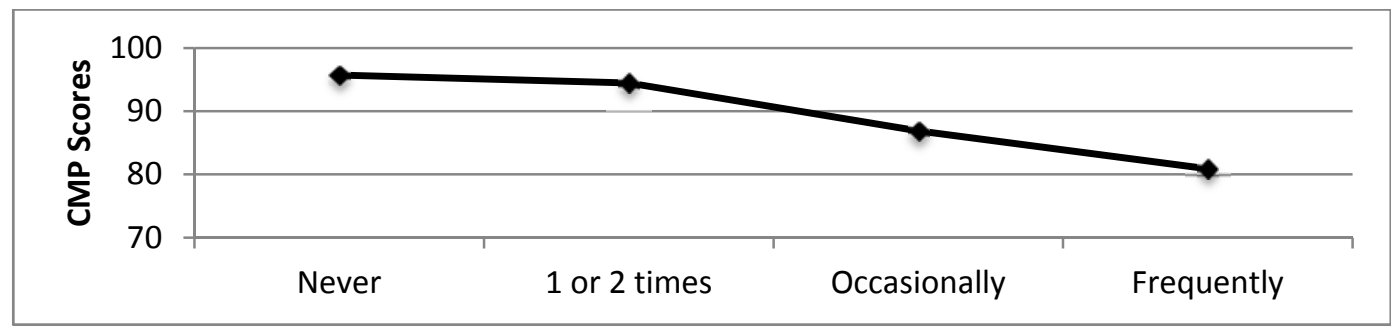

Faculty members were also asked how often they engaged in research collaborations with community partners. Post-hoc comparisons for the significant $\operatorname{ANOVA}[\mathrm{F}(3,110)=$ $5.71, \mathrm{p}=.001]$ indicated that those who never engaged in such projects scored significantly higher $(\mathrm{M}=99.1, \mathrm{SD}=25.4)$ on the CMP scale than those who did so frequently $(\mathrm{M}=$ $76.7, \mathrm{SD}=21.4)$. This effect size was large $($ Eta-squared $=.13)$.

\section{New Graduates}

New BSW graduates were also asked some unique questions regarding their educational experiences. Sixty-three percent of this subsample indicated that they had completed five or more courses that included community service. These students were compared with those who said they had taken fewer courses with community service components, but no statistically significant difference in CMP scores was indicated. However, new graduates who reported that they had frequently participated in service events as part of a social work club had significantly lower scores (more civic-minded) $[\mathrm{F}(2,38)=5.07, \mathrm{p}=.011]$ than those who had not. This effect size was large (Eta-squared $=.21$ ). No significant differences in CMP scores were found between students who were seeking full-time employment, had secured employment, or were starting a graduate program.

\section{Community Social Workers}

Social workers in the community (not educators or new graduates) were also asked some unique questions. No significant relationship was indicated between years of 
experience and CMP scores $[\mathrm{F}(6,88)=2.0, \mathrm{p}=.07]$. Group differences based on frequency of experience acting as field supervisors for social work students were not statistically significant $(\mathrm{p}=.079)$ either; however, examining the trend in the mean plot (see Figure 3 ), it appears that the relationship may approach significance.

Figure 3. Mean Plot of Civic-Mindedness by Frequency of Field Supervision

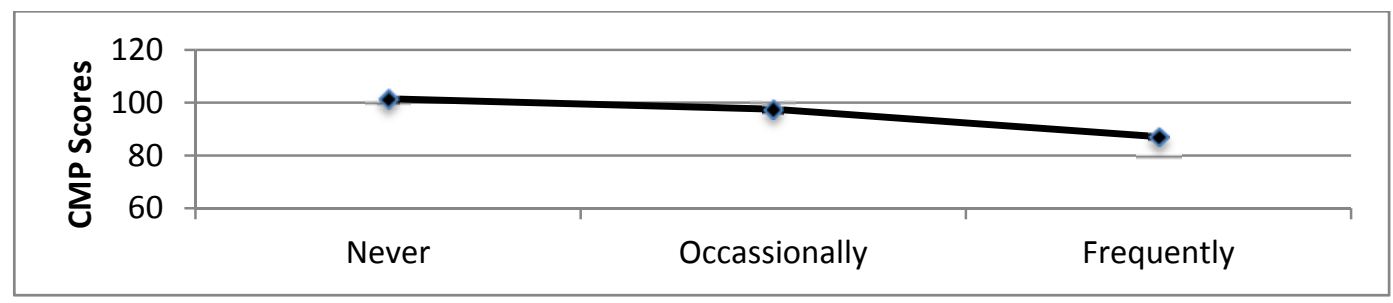

Most community social workers indicated that they had never collaborated with faculty on research. Nevertheless, those who had were more civic-minded $(\mathrm{M}=88.1, \mathrm{SD}=22.6)$ than those who had not $(\mathrm{M}=100.8, \mathrm{SD}=27.0)$. This difference was statistically significant $[\mathrm{t}=2.4, \mathrm{p}=.02)$ and the effect size was moderate (Cohen's $d=.51$ ).

\section{Discussion}

The results of the analysis appear to indicate that there are some important differences in civic-mindedness among social workers. In the overall sample, social workers who belonged to NASW and who participated in political activities with more frequency were more civic-minded. This finding is similar to Ritter's (2008) that indicated that NASW members were more likely to participate in political activities.

Faculty rank or membership in an educationally related professional organization appeared to have no relationship with civic-mindedness among social work educators in the sample. However, faculty members who reported that they made efforts to engage their students in civic issues through community service or class materials were also more civicminded themselves. This matched expectations, based on previous research; Hatcher (2008) found that faculty members who were nominees for national service awards were more civic-minded than those not nominated, and that faculty members who utilized service-learning pedagogy were more civic-minded than those who did not employ this strategy. Additionally, more civic-minded faculty members in our sample were more likely to have engaged in research with community partners. This result seems to make sense based on the assumption that faculty who partner with community agencies to conduct research value the knowledge and expertise of the practitioner partners. Hatcher (2008) also found that faculty engaged in collaborative research were more civic-minded than those who did not conduct this type of research.

In spite of a professional expectation of pro bono service (NASW, 2008), more than half of the sample respondents indicated that their jobs fulfilled their obligation to volunteer. Faculty members were least likely to endorse this idea; however, statistical comparisons were non-significant. Social work educators were the least likely to agree that their jobs fulfilled their obligation to donate financially while new graduates were the most 
likely to agree. Perhaps new graduates have fewer financial resources than faculty or community social workers.

Other comparisons were more surprising. The researchers found it particularly interesting that while there appeared to be differences between educators and community practitioners in civic-mindedness, there appeared to be little difference between traditionally-defined "faculty" members and field faculty (community practitioners of social work who regularly supervised social work students in field placements but are not formally employed by the college or university). While the researchers cannot establish whether more civic-mindedness professionals are attracted to teaching or the act of teaching impacts civic-mindedness, social workers who have higher levels of contact with students also appear to be more focused on civic responsibility. This has interesting implications and deserves further attention.

While civic-mindedness among faculty did appear to differ based on their use of community service in pedagogy, the results did not pick up on the same difference for social work learners. Faculty members who used specific methods to influence the civic engagement of students were more civic-minded than their colleagues. However, students with more "community service courses" were not more civic-minded than their peers. But those who frequently did community service activities in a social work club were more civic-minded than students who did not. These findings appear different from other research results; Fenzel and Payrot (2005) found that course-related service had more impact than general service. It is possible that social work students have significantly

different educational experiences than students in other disciplines. Less than $5 \%$ of the student sample reported they had never taken a course with a service component and the majority indicated they had taken 5 or more of these courses; therefore, subtle differences on the impact of this pedagogy would be hard to detect. Additionally, this may not be a linear relationship, there may be a saturation point, or students may define what community service means differently than faculty members or researchers. Perhaps social work students place more significance on community engagement activities that occur outside the classroom and are therefore more "voluntary".

Civic-mindedness was also higher among social workers who engaged in collaborative research projects, whether faculty or community practitioners. This finding would seem to reinforce the idea that more of this type of activity is needed.

\section{Limitations}

As with all research, there were limitations to the study. The researchers used a crosssectional design; all the data was collected from participants at one point in time. Because of this, time order cannot be established. This is an important point with this research as the direction of relationships cannot be determined. For example, does a higher level of civic-mindedness lead professionals to join NASW or does belonging to NASW lead to being more civic-minded? Are civic-minded students more likely to join student clubs or do student clubs build civic-mindedness? The researchers cannot answer these causal questions with this study design. Social desirability could also be a significant limitation in the study. The respondents may have answered questions in a way that indicated the way 
they thought they should act or think as social workers, rather than the way they actually do. This problem would probably be more of an issue with the social work profession, with our strong value base and code of ethics, than with other professions on which civicmindedness has been explored. Other limitations include a non-random sampling method, a relatively small sample size, and the possibility of self-selection bias. However, the similarity between some of the findings and those of other related studies increases our level of confidence in the representativeness of our sample.

\section{Implications}

These findings suggest several ways in which the social work profession can strengthen civic-mindedness. Social workers have the opportunity to create spaces with their colleagues to engage in community action for the common good. Thinking deliberately about these opportunities, many of which are already in place at universities and in the community, may help nurture the next generation of social workers.

Social work educators were the most civic-minded group in the sample. They also come in contact with other social workers as part of their daily work. One way faculty could promote civic-mindedness is to conduct action research with community partners. Ideally, a community social worker or a student would be a co-investigator on the research project. Participation with the faculty member in action research gives the community social worker or student an opportunity to learn or enhance research skills, while at the same time creating knowledge that is practical for the agency setting. Action research benefits the faculty member and the social service agency; a faculty member gains access to a population or data set needed in order to create scholarly knowledge, and the community agency gets the research experience of a faculty member. Often community agencies want to conduct research, but lack the time, expertise, and access to the scholarly literature that faculty members have.

The finding that field supervisors had similar levels of civic-mindedness to social work educators was an interesting outcome that deserves additional attention. Social work programs can use this to their advantage; most programs have traditionally seen field supervisors as in integral part of a student's education, but have focused their educational role and scope to helping students develop practice skills. Social work programs could host a training for field supervisors that emphasizes CSWE Competency \#1, "Identify with the social work profession and behave professionally" and the associated Practice Behaviors (CSWE, 2008). The reinforcement of the civic-minded attitudes that field supervisors already have could help them explicitly emphasize this professional obligation to the students with whom they work. Having field supervisors purposefully model and discuss civic-minded behaviors with their students would further promote the values and expectations of the profession.

Community social workers were less civic-minded than educators, their colleagues who were field supervisors, and graduating seniors. One might expect that levels of civicmindedness would have influenced beliefs that formal employment fulfilled obligations to volunteer or financially give; however, that was not the case. There were no differences in these behaviors between the groups. Future research is warranted to determine factors, such 
as burnout or job duties, which may contribute to differences in community social workers' civic-mindedness, as well as willingness to volunteer and donate monies.

One way to combat declining civic-mindedness among community social workers may be to increase opportunities to engage with social work programs and students. In many cases, community social workers may be alumni of local universities and social work programs. Social work departments could work with the Alumni Association to host a community service event. For example, on Martin Luther King (MLK) Day of Service, social work faculty, community social workers, and the social work club could partner to complete a community service project. NASW membership was high in this sample, and the local chapter may be another willing participant in such an event. Bringing together social workers from different backgrounds and stages of professional development could produce multiple positive outcomes such as reconnecting alumni with their universities, creating networking opportunities for community social workers, and providing students at all stages of their academic careers with a chance to meet and interact with practicing social workers, while at the same time, serving the community.

Finally, students who participated in community service as part of the social work club were more civic-minded than their peers who did not. Social work clubs have traditionally been seen as a co-curricular opportunity for students to develop leadership roles and engage in community service. Being intentional about club advising, the variety of opportunities that the club offers, and making sure pre-social work majors are invited to club activities might be a step in the right direction. Giving consideration to the times of day the club meets or the type of service opportunities that are planned (e.g., one-day vs. ongoing volunteer commitment) may encourage more students, including non-traditional or other diverse groups, to participate.

\section{Conclusion}

How social workers view their commitment to civic engagement and the public good has implications for the profession. The results of this study suggest that social workers see themselves as agents who engage in work necessary for social change. As such, revisiting the work of Specht and Courtney (1994) to contemplate how civic-minded attitudes can translate into behavioral change is warranted. Using their writings as a framework to examine professional obligations, intentional practices, such as the service learning projects and research collaborations examined in this study, could be implemented to reinforce and strengthen the partnerships between the groups in order to better adhere to the values of the profession.

\section{References}

Astin, A. W., Sax, L. J., \& Avalos, J. (1999). Long-term effects of volunteerism during the undergraduate years. The Review of Higher Education, 22(2), 187-202. Retrieved from http://www.press.jhu.edu/journals/review of higher education/

Bipartisan Policy Center. (2012, November 8). 2012 Voter Turnout. Retrieved from http://bipartisanpolicy.org/library/report/2012-voter-turnout 
Bransford, C. L., \& Choi, S. (2012). Using interpersonal psychotherapy to reduce depression among home-bound elders: A service-learning research collaboration. Best Practice in Mental Health, 8(1), 1-15. Retrieved from http://lyceumbooks.com/MentalHJournal.htm

Cohn, D., Passel, J. S., Wang, W., \& Livingston, G. (2011). Barely half of U. S. adults are married - a record low. Retrieved from http://www.pewsocialtrends.org/files/2011/12/Marriage-Decline.pdf

Colby, A., \& Sullivan, W. M. (2009). Strengthening the foundations of students' excellence, integrity, and social contribution. Liberal Education, 95(1), 22-29.

Council on Social Work Education. (2008). Educational Policy and Accreditation Standards. Retrieved from http://www.cswe.org/File.aspx?id=13780

Fenzel, L. M., \& Peyrot, M. (2005). Comparing college community participation and future service behaviors and attitudes. Michigan Journal of Community ServiceLearning, 12(1), 23-31. Retrieved from http://ginsberg.umich.edu/mjcsl/

Gibelman, M., \& Sweifach, J. (2008). Acting on our values: Do social workers volunteer? Social Work, 53(1), 53-64. Retrieved from http://www.naswpress.org/publications/journals/sw.html

Gil de Zuniga, H., \& Valenzuela, S. (2011). The mediating path to a stronger citizenship: Online and offline networks, weak ties, and civic engagement. Communication Research, 38(3), 397-421. doi:10.1177/0093650210384984

Gillham, O. (2002). The limitless city: A primer on the urban sprawl debate. Washington, DC: Island Press.

Hampton, K. N., Goulet, L. S., Marlow, C., \& Rainie, L. (2011). Social networking sites and our lives: How people's trust, personal relationships, and civic and political involvement are connected to their use of social networking sites and other technologies. Retrieved from http://www.pewinternet.org/ /media//Files/Reports/2011/PIP\%20\%20Social\%20networking\%20sites\%20and\%20our\%20lives.pdf

Hampton, K. N., Goulet, L. S., Marlow, C., \& Rainie, L. (2012). Why most Facebook users get more than they give: The effect of Facebook 'power users' on everybody else. Retrieved from http://pewinternet.org/ /media//Files/Reports/2012/PIP_Facebook\%20users_2.3.12.p $\underline{\mathrm{df}}$

Hatcher, J. A. (2008). The public role of professionals: Developing and evaluating the civic-minded professional scale. Available from ProQuest Dissertations and Theses. Retrieved from http://search.proquest.com/docview/304606370?accountid=7398 (UMI No. 3331248)

Kenny, M. E., \& Gallagher, L. A. (2002). Service-learning: A history of systems. In M. E. Kenny, L. K. Simon, K. Kiley-Brabeck, \& R. M. Lerner (Eds.), Learning to serve: 
Prompting civil society through service learning (pp. 15-29). Norwell, MA: Kluwer Academic Publishers.

King, M. E. (2003). Social work education and service learning. Journal of Baccalaureate Social Work, 8(2), 37-48. Retrieved from http://www.sowo.tcu.edu/jbsw/

Lowe, L. A., \& Medina, V. (2010). Service learning collaborations: A formula for reciprocity. Families in Society, 91(2), 127-134. doi:10.1606/1044-3894.3970

Mary, N. L. (2001). Political activism of social work educators. Journal of Community Practice, 9(4), 1-20. doi:10.1300/J125v09n04_01

Mink, T., \& Twill, S. E. (2012). Using service learning to teach a BSW policy course. Journal of Community Engagement and Scholarship, 5(1), 5-13. Retrieved from http://jces.ua.edu/

Morris, R. (2000). Social work's century of evolution as a profession: Choices made, opportunities lost. From the individual and society to the individual. In J. G. Hopps \& R. Morris (Eds.), Social work at the millennium: Critical reflections on the future of the profession (pp. 42-70). New York, NY: The Free Press.

National Association of Social Workers. (2008). Code of Ethics. Retrieved from http://socialworkers.org/pubs/code/default.asp

Norris, D. S., \& Schwartz, C. L. (2009). Needs assessments: An integrated assignment in civic service. Journal of Teaching in Social Work, 29(4), 373-382. doi:10.1080/08841230903022027

Organization for Economic Cooperation and Development. (2011). Better Life Index: Work-life Balance. Retrieved from www.oecdbetterlifeindex.org/topics/work-life$\underline{\text { balance/ }}$

Pond, A., Smith, G., \& Clement, S. (2010) Religion among the Millennials: Less religiously active than older Americans, but fairly traditional in other ways. Washington, DC: Pew Forum on Religion and Public Life. Retrieved from www.pewforum.org/Age/Religion-Among-the-Millennials.aspx

Putnam, R. D. (2000). Bowling alone: The collapse and revival of American community. New York, NY: Simon \& Schuster.

Ritter, J. (2008). A national study predicting licensed social workers' level of political participation: The role of resources, psychological engagement, and recruitment networks. Social Work, 53(4), 347-357. doi:10.1093/sw/53.4.347

Rocha, C. J. (2000). Evaluating experiential teaching methods in a policy practice course: The case for service learning to increase political participation. Journal of Social Work Education, 36(1) 53-63. Retrieved from www.cswe.org/CSWE/publications/journal/

Specht, H., \& Courtney, M. E. (1994). Unfaithful angels: How social work has abandoned its mission. New York, NY: The Free Press. 
Sullivan, W. M., \& Rosin, M. S. (2008). A life of the mind for practice: Bridging liberal and professional education. Change, 40(2), 44-47.

Taylor, P., Funk, C., \& Craighill, P. (2006). Home "ticket sales” dwarf theater attendance 5-1, survey shows: Increasingly, Americans prefer going to the movies at home. Washington, DC: Pew Research Center. Retrieved from www.pewsocialtrends.org/files/2010/10/Movies.pdf

Verba, S., Schlozman, K. L., \& Brady, H. E. (2000). Rational action and political activity. Journal of Theoretical Politics, 12(3), 243-269.

Williams, N., King, M., \& Kobb, J. (2002). Social work students go to camp: The effects of service learning on perceived self-efficacy. Journal of Teaching in Social Work, 22(3/4), 55-70. doi:10.1300/J067v22n03_05

Zhang, W., \& Chia, S. C. (2006). The effects of mass media use and social capital on civic and political participation. Communication Studies, 57(3), 277-297. doi:10.1080/10510970600666974.

\section{Author note}

Address correspondence to: Sarah E. Twill, Ph.D., 270 Millett Hall, Wright State

University, Dayton, OH 45435. Email: sarah.twill@,wright.edu 